\title{
Monstrous Desires and Disinterested Appreciation: Architecture, Technique and Nature
}

\author{
Vela Castillo, José \\ le University, Arquitectura, Segovia, España, jvela@faculty.ie.edu
}

\begin{abstract}
Resumen (293 palabras)
Parece que en las últimas décadas la arquitectura ha comenzado finalmente a tener en cuenta el impacto que tanto su construcción como su puesta en funcionamiento tienen sobre el medio ambiente. Ello ha llevado a una transformación estética de la arquitectura para hacerla (parecer) más ecológica que se ha resuelto en gran medida mediante el uso extensivo de la técnica, incorporando y exhibiendo una batería de sistemas tecnológicos que buscan la máxima eficiencia, pero que sin embargo no atacan las raíces de la cuestión. Pues lo que en realidad hace falta es replantear en el origen las relaciones entre arquitectura, técnica y naturaleza, en busca de un comienzo alternativo. Este artículo propone en primer lugar un repaso a esta relación original, que de hecho es una relación contaminada desde el principio y condenada a su fracaso, aproximándose a su mito fundacional, el de Dédalo. A partir de ahí, se propondrán dos estrategias generales que la arquitectura puede ensayar para reconstruir, o al menos aliviar, esta difícil relación: una arquitectura de la visibilidad (y por tanto que sea crítica) y una arquitectura de la gratuidad (y que por tanto sea desinteresada). A ello seguirá un desarrollo más pormenorizado de las cuestiones en discusión, como la necesaria negociación hombre/arquitectura y naturaleza, las cuestiones relacionadas con el uso retórico de las tecnologías verdes, las demandas que estas estrategias de visibilidad y gratuidad implican y las relaciones entre physis y techne, para terminar con la cuestión del desinterés desde una óptica kantiana. Las breves conclusiones finales nos devolverán al punto en que se reconsidera, en vez de un origen para la arquitectura que impone una relación técnica (de explotación) con la naturaleza, un posible origen estético que imponga, en cambio, una relación desinteresada con la misma.
\end{abstract}

Palabras clave: arquitectura, estética, medio ambiente, exceso

\begin{abstract}
(295 words)
It seems that in the last decades architecture has finally become aware of the impact the demands of its construction and of its maintenance and operation have on the environment. The demands for architecture of being green or becoming ecological have been answered mostly through an enhanced use of technology, through a technical deployment of a multiplicity of systems and gadgets that try to achieve a better performance, or in other words, a better efficiency, but not by addressing the roots of the question. Henceforth, this increase in the use of technology is covering the fact that what architecture needs to do for being green is not to promote the use of technology, but to rethink its original relation with technique and nature. This paper will propose in the first place a brief survey of this original and tainted relation between architecture, technique and nature, to show how and why this relation was condemned since the beginning. Then, I will propose in the first place two strategies to fight this original misunderstanding: an architecture of visibility, which should be a critical one, and an architecture of gratuity, that should necessarily be a disinterested one. It will follow a review of some of the questions already mentioned with more detail, addressing the question of a necessary negotiation with nature, the issues posed by the rhetorical use of green technology, the demands of transparency and gratuity in architecture, the relations between physis and techne, and the important question of disinterest through the lens of Kantian aesthetics. In a final and short conclusion I will propose, instead of a technical substratum for the relations between architecture and nature, an aesthetical one, that can anticipate a relation between man and nature based in disinterest instead of extraction and domination.
\end{abstract}

Key words: architecture, nature, technique, visibility, disinterest 


\section{THE TAINTED RELATION BETWEEN NATURE AND TECHNIQUE}

Architecture and technique conform a conceptual and physical pairing, it can be said, at least from the origin of Western civilization, the too much longed ancient Greek primeval time in which both seem to merge into the dark and the same outrageously clear- burning Mediterranean sun-epoch of the myth. First mythical architect, Daedalus, holder of a nearly-magical technique, produced among other substantial inventions two of the most striking concoctions of human imagination: the mechanical wooden cow in which queen Pasiphae hid herself to satisfy her unnatural yearning for a beautiful white bull-a mechanical and delusive instrument-and the labyrinth in which the result of this monstrous union, the Minotaur, will be confined-the first architecture ever designed. ${ }^{1}$ Both inventions, the mechanical cow and the architectural labyrinth clearly represent what, from this point on, will be the paradigmatic approach of Western civilization to nature, making only too clear the impossibility of coming to terms with something that at the same time we are afraid of and we lust for. Man being "nature" anymore after Prometheus stole the sacred fire and allowed technique to appear in another myth worth to be revisited, from this point on technique will allow man to exert control over nature, virtually surrendering it to its own monstrous desires, and transforming the remnants into the object of man untamed interest. Of course nature will take some revenge... if only because this initial metaphysical divide here set up for the first time will, more than 2.500 years later, reveal its catastrophic consequences.

Daedalus inventions, then, will allow man to dominate nature after his or her desires in the same way that queen Pasiphae's artifact allowed her to dominate the white bull, a not so obscure metaphor for nature in its wild, dangerous but also engaging form, and to satisfy her desires with(in) it. Daedalus second invention, the labyrinth, will permit, too, to extend this control extensively and domesticate nature by confining it into the human technical structure of architecture. And even more, to follow on with the story told by the myth, since some time later the young Athenian Theseus, killing the Minotaur after a cunning trick worth of Ulises but in fact provided by a woman, Ariadne, will definitively certificate the division, thoroughly extending the control of man over nature-and man, here, is masculine and profits of the female as he disposes of nature too. ${ }^{2}$ Of course this is only a myth, but a myth worth to be considered in its foundational character. Daedalus inventions, including architecture, signed the death certificate of nature, and at the same time provided its replacement, technique, actually forbidding any possible negotiation between the two, since from this point on the relationship will be the one between master and slave and between interested extractor and forced extracted. And slaves do not negotiate with masters: they either obey or kill them. Almost sure we are reaching the second possibility.

In any case, this original myth provides some ideas about what is wrong with the technical or techno-scientific approach through which present day society considers nature, including architecture as the important actor it is, and despising the voices that are crying — true, louder and louder - in the desert in view of the impending disaster, tries to restore a long-lost equilibrium precisely by developing more and more new technologies. Since, if technique is at the root of the question of this subjection of nature to man, if it is precisely the reason of the invention of the technical and its original use the will to subject nature to man demands, if technique is, finally, the tool that substantiates this interested conception of nature by man, it cannot therefore be the solution. Or at least it cannot be if we do not reformulate two of its basic premises. Hence it is maybe necessary to, on the one hand, get rid of the delusive part technique has - the wooden fake cow, the tricky Ariadne's thread, the hoax Prometheus used to steal the fire-, and on the other, to come back to terms with nature through negotiation and not through imposition, through a political—democratic — discussion instead of a power imposition: through disinterest, hence stating the equivalence between the two. Or using different words, we need to develop a less transparent relation with nature based precisely in visibility (real or figured) which acknowledges a real political statute to both, humankind and nature. Or yet in other words: it is necessary to establish a different economy in the human-nature relation, one in which both pairs of the relation, instead of being understood as exclusive terms inside and oppositional logic were understood as being constantly redefined in its own terms, since they are both revealed as mutually dependent if not as qualifications of one and the same world. Paradoxically as it may seem, this economy, instead of an economy of surplus which demands profit-as capitalism is-, should be an economy of excess, which demands gratuity.

Consequently, I will try to propose through this paper, although in a tentative way, unstable and excessive yet

\footnotetext{
${ }^{1}$ For a general account of Daedalus inventions see Françoise Frontisi-Ducroix, Dédale. Mythologie de l'artisan en Grèce ancienne (Paris: Librairie François Maspero, 1975).

${ }^{2}$ Athenian hero Theseus was, in fact, renowned by the fact that he dispensed women with a not so decent treatment, including Ariadne, Helen and Persephone, all of them goddess or semi-goddess directly related with vegetation and nature. For a good account of Theseus myth, see Henry J. Walker Theseus and Athens (New York and Oxford: Oxford University Press, 1995). The book is especially relevant to understand the role Theseus had in configuring the imaginary of the Athenian citizenship.
}

Aesthetics Of Architectura: An Environmental Excess. José Vela Castillo.

DOI 10.14198/i2.2015.03.04 
open and promising, an architecture of both visibility and gratuity; a disinterested architecture.

On the one hand, visibility is the necessary precondition to reveal, to make evident, the monstrous coupling that made nature a surrogate of man. Instead of confining its invisible (in the sense of not allowed to be seen) result, the Minotaur, inside a treacherous architecture, the labyrinth, visibility should make clearly perceptible to the eye what otherwise will remain transparent: the enormity of the abuse. Making things visible is providing a clue to orientation inside the labyrinth, a sort of Ariadne's thread which can reveal the steps we have taken; but it is also giving them a body, a solid body that opposes total transparency and links again our actions with their effects.

On the other, gratuity stands here for disinterest, which at the end of the text will reconnect our argument with Kantian aesthetics, but it also redirects us to an economy of the gift, an economy that, as Marcel Mauss established some hundred years ago, imposes a triple demand: "the obligation to give, the obligation to receive and [the obligation to] reciprocate.." ${ }^{3}$ An economy, then, that is necessarily redistributive and aims for equality instead of being extractive and aimed to profit. Although one that is not free of dangers in the form of the cumulative nature of excess, which at the end will result into a debt impossible to reciprocate. ${ }^{4}$ Of course we have to understand here gratuity in its double meaning of being free and being in addition to. It is important, then, to point to both its significance as tip, as something that is given in addition, that exceeds the agreed, as a kind of supplement but on the other hand we must remember that this gratuity is offered cost-free, gratis, that we do not have to pay for it. In that second sense gratuity is offered as a present, as a gift, as something (at least apparently) with no interest, that is to say disinterested. Without rest or remnant since the equivalence is perfect in the economy of the gift (or is supposed to be so). Nevertheless, and as Derrida reminded us, we have to be suspicious, since in fact, gifts as gifts are impossible, or better saying, they propose an ideal impossible to achieve (an ideal, in any case, worth the try). ${ }^{5}$ For something as a gift to exist, a pure gratuity offered without interest and without any kind of perspectives of being returned - no future profit and no delayed reward —as a real gift must be, for this especial kind of gift to exist, neither the donor nor the receiver can truly realize that this gift is precisely a gift. The moment the act of giving is acknowledged as such, it is spoiled by interest, like it or not. It is tainted by either the hidden or the open desire to be reciprocated or by the uncomfortable feeling of being in debt.

\section{RE-NEGOTIATING WITH NATURE}

The first point to stress here is the necessity of reestablishing a different relation with nature, which leads to the necessity of renegotiate the conditions after which this relation was set up in the original myth. And this is not what the majority of architecture today is doing, even when considers itself green architecture. In any case maybe renegotiate is not the right word, because it seems to imply at least two assumptions I can not necessarily concede so easily as true, the particle re- always implying the returning of a previous condition, of something that comes again to presence, in the bases of either a temporal or a logical priority. The first assumption is that we can "negotiate" with nature, something which of course is neither granted nor obviously deduced from direct observation and/or physical perception and intellectual apprehension. Nature, though nevertheless in some ways a human construction, it is also a limit or condition of possibility. From the old medieval opposition between natura naturans ("nature in the act of naturing", active nature) and natura naturata ("nature as produced nature", created nature) later rewritten by Spinoza, ${ }^{6}$ to nature understood as the irreducible core or nucleus of intelligibility of the world, or in the Heideggerian critique of modern techno-science nature used as a mere reservoir at our disposal, ${ }^{7}$ nature is "something" that exceeds any possibility of negotiation but at the same time demands it more and more urgently. It is constantly configured as an-other, and in fact even as the absolute Other, and we can only rearrange our position in relation with it, but we cannot displace its own position except at the risk of making it disappear, or so it has been assumed. Hence it seems that it is not possible to negotiate with nature as an entity beyond ourselves (or before), and this implies, of course, the necessity of an alternative concept of nature, an all-encompassing

\footnotetext{
${ }^{3}$ Marcel Mauss, The Gift: The Form and Reason for Exchange in Archaic Societies (London: Routledge, 2002. First published 1925), 50.

${ }^{4}$ For a more developed account of such an economy, an economy of the (impossible to return) debt, see José Vela Castillo, "I owe you an explanation". REIA \#3 (2014): 183-198.

${ }^{5}$ See Jaques Derrida, Given Time: I. Counterfeit Money (Chicago and London: The University of Chicago Press, 1992). For example this quote from note 23 in page 69: '[...] the gift not only owes nothing, remains foreign to the circle of the debt, but must not answer to its own essence, must not even be what it has to be, namely, a gift.'

${ }^{6}$ Spinoza will propose this distinction in his Ethics. For him natura naturans is easily identified with God, eternal, unchanging, but active principle of everything and natura naturata with "nature" as we know it, contingent, apparent, in constant change.

${ }^{7}$ For Heidegger and his concept of Ge-stell or "enframing", which for him is the essence of the techno-scientific appreciation of nature, see Martin Heidegger "The Question Concerning Technlogy" in The Question Concerning Technology and Other Essays (New York and London: Garland, 1977), 3-35. But for Heidegger, Ge-stell is precisely linked not only with techne, with technology, but with the poetic (poiesis) too.
}

Aesthetics Of Architectura: An Environmental Excess. José Vela Castillo.

DOI 10.14198/i2.2015.03.04 
concept that instead of dividing nature and humans as object and subject, acknowledges a certain political capacity to nature itself, a certain agency that is similar and that specifically interacts with human agency, hence making negotiation possible. This line of thought can be found, although still in a tentative form, in recent developments in philosophy, sociology of science and other fields, and can be exemplified in the writings of Bruno Latour among others.

The second assumption is that, since I used the particle "re" to qualify "negotiate", language assumes this negotiation in fact has happened (always) before, in a long distant past or in a primeval Golden Age where men were like demi-gods, before the Fall and in-between the forest full of apples where Adam and Eve walked hand in hand. That is to say in a time when in fact this negotiation did not need to take place, because men were no different of nature and because they were bounded to rules that, so to say, matched them perfectly (as happen also with gods), without rest/remainder/residue/remnant: perfect equivalence of the gift. But this relationship, in fact, came not as a voluntary or negotiated one, but as an imposition or subjection, in that case from nature upon men. Or more precisely as a constituent element of what we call "the human", that is given from before and from above. So there was no transaction, in fact no intellectual knowing of the real existence of these rules, only compliant with them. No negotiation then: only a subjection but one mediated through technique as men discovered after being expelled from the primeval garden of Eden and needed precisely technique to dress, build, warm up and so on. It is important not to overlook the rich semantic field opened by the word "subject", which refers in the first place to the substratum, to which is under as a support, to the deep "nature" or essence of what appears to presence. To summarize: when man was part of nature, before any division, no negotiation need to take place; but when man began to understand himself as "human" and discovered technique and began to build, the negotiation happened to be impossible. ${ }^{9}$

\section{ARCHITECTURE AND THE RHETORICAL USE OF GREEN TECHNOLOGY. VISIBILITY, EFFICIENCY, EXCESS}

Many architectures designed and built in recent times have become obsessed with the question of its mechanical insertion in the environment, achieved through a supposedly revolutionary becoming-green through the magical aid of technology. This promoted the economical re-appropriation of a rhetoric of wilderness. This approach nevertheless seems to be achieved basically through the massive use of technology, in what seems a zero cost procedure at first sight but which in fact is an expensive one that involves many collateral environment damages. Certain architectural practices of today try to clean their image and to project an ecological sophistication not always at a reasonable cost. Putting into practice a myriad of technical devices for the sake of its esthetical expression allow them to mask through a trendy use of some well-established green images the radical forgery of the whole enterprise. Filed under eco-architecture, bleaching green, ecoLogical and so on architects and technicians but specially building companies and campaigning politicians, have become obsessed by-and auto-imposed with—a new green belief, that, nevertheless, in much more cases than is necessary face the energy saving problem through the use, the abuse and specially the exhibition of the mechanical - the techno-scientific - ad-hoc gadgetry. Hence relegating architectonical values and especially those related with place to an almost anecdotic background.

Not that architecture and our whole imprint upon the planet must not be rethought in terms of sustainability, acknowledged the limited resources for an increasing world population and even more increasing supplies demand. But precisely because that, we cannot satisfy ourselves with enveloping architecture in a "green coat", in a mechanically efficient second skin that, at best, can temporarily alleviate the pressure on earth resources and at worst only produces the effect of hiding the problem and taming our consciences.

\footnotetext{
${ }^{8}$ As Isabelle Stengers. In both them the concept of Cosmopolitics plays an important role in the redefinition of present ideas on nature, politics and the life together of nature and humans. Recently, Bruno Latour has been working with the overarching figure of Gaia, which in his vision is Earth understood not as a system, composed of many things including nature and humans, but as something that has history, or more precisely, geohistory. Being our world now inside the (new) geological era of the Anthropocene, one in which human agency achieved the same dimension that precedent geological forces in shaping the earth, what is now demanded is a new politics that acknowledge the fact of the different agencies in Gaia, and can bring peace to the war between them. Of course, a footnote is not the place to develop these ideas, which at the moment exceed the content of this article. Nevertheless, at least a short mention was needed. See Isabelle Stengers, Cosmopolitics volume I and II (Minneapolis, MN: University of Minnesota Press: 2010 and 2011). For Bruno Latour it is worth looking at the Gifford lectures he gave at Edimburgh University in 2013, (retrieved August 18, 2015) on the topic "Facing Gaia. A new Inquiry into Natural Religion."

http://www.ed.ac.uk/schools-departments/humanities-soc-sci/news-events/lectures/gifford-lectures/archive/series-20122013/bruno-latour

${ }^{9}$ For the question of men in and out Paradise, and what it implies in political terms, see José Vela Castillo "Aunque la mona se vista de seda mona se queda? Desnudez, animalidad, política y ciudad" en Revista Desierto \#3, "28 Celsius" (2014): 97-106.

Aesthetics Of Architectura: An Environmental Excess. José Vela Castillo.
}

DOI 10.14198/i2.2015.03.04 
Although being technical as it has been said, architecture in its technicality does not imply as a secured corollary that it must continually display identitary aesthetical sign of its technical display. Moreover, the technological display would lead to an aesthetical appreciation of the careful engineered gadgets which will obscure the hidden agenda of any industrial production: its impossible total efficiency. Every technical production has its costs in terms of energy and resource consumption as thermodynamics taught us a long time ago, and improving efficiency, good as it is, can never reach the point of a neutral balance.

In that sense, most of green architecture is a tricky one, since it plays the game of the efficiency to mask its unsustainability: if the energy consumption of a building can be reduced through the use of advanced mechanical systems with a better efficiency rate-better photovoltaic solar panels, better heating and cooling machines, better lightning systems with low consume bulbs, better systems of controlling natural ventilation, use of "clean" energy like that provided by windmills or geothermal energy and so on - it seems that we can still have the same or slightly smaller level of consumption without disquieting our conscience - but not the environment. Accordingly we do not have the urge to reconsider our comfortable way of living in our globalised and "eco-friendly" first world.

In addition, there is also a global pressure in the quest of efficiency that affects all the aspects of present day economy. Post capitalist or globalized economy is in search, desperately maybe said, of efficiency understood as cost reduction and profit increases. This, of course, is no news, and capitalism has been looking after efficiency since its generalization since, say $18^{\text {th }}$ century. Taylorism and Fordism at the end of $19^{\text {th }}$ century clearly exemplifying this inner drive. What seems to be new is that this quest for efficiency is now boastingly advertised as a concern with the planet and ecology, and has been developed as a sales strategy to ultimately mask its perverse intentions. Nevertheless, the unmoral and pornographic quantities of money earned with the implementation of this logic of efficiency in the market have a cost. A cost measured in terms of shortness and scarcity, in terms of unbalanced poverty, in terms of accelerated reduction of resources, even in terms of pure and simple survival. The supplementary logic of this economical reappropriation, the perverse logic by which efficiency instead of produce savings is directly transformed into consume, regardless the consequences in the future, is an unbearable one.

What I advocate here for is, on the hand, the visibilization of the costs this obsession with efficiency has in architecture, and on the other for a reversal of the kind of logic involved in the process. It is then absolutely necessary to make the ecological footprint of architecture visible through a real eco-architecture, because architecture has the moral obligation of showing its costs and because we as users of this fabrication are in need of knowing the real outcome of the whole of process. And I'm not saying that we as customers have the rights of knowing, that of course we have, but that we as living beings in first world should be confronted with the real bill, wanted or not. Not only buildings must have letter classification, like washing machines and refrigerators, to assure its low consume. They must show, for being honest with its green concern, its whole carbon footprint, past and future, and must also tell us clearly that we being humans in planet Earth, do not have the possibility of reaching total efficiency: the final balance will always be a negative one, if not in the present, then in the near future. And, although this paper is not directly concerned with actual examples of architecture, we can have a good illustration of this visualizing practices, and it is especially important given the significance of the place in which it is built, in the recent COSMO water-purifying structure Andrés Jaque / Office for Poltical Innovation have built at the MoMA PS1 in New York, active during the months of June to September 2015.

In addition to that, a reversal of this combined logic of efficiency an excess into a logic of inefficiency and gratuity is desperately needed. And here it is necessary to introduce a different idea of what excess means or what it serves for but also what the costs of excess are. The excess I here propose architecture has to take into account is costless, is for free. It is a gift. The line that divides the "good" excess, the gratuity and the excess that comes from obscene accumulation and unrestrained consume must be constantly retraced, but couldn't be forgotten or diminished as a question of the past. In fact, it is the question of the future. Any new architecture, then, has to make an effort to understand its own nature in terms of gratuity and disinterest, contributing with more than is asked to provide, although it can never forget, nevertheless, the impossibility of the task. True architecture, good architecture, has been always at the same time efficient and inefficient, considered in terms of economy and aesthetics. A building — but also a book or a painting - always gives back more than was originally intended to provide, either in terms of aesthetical appreciation, meaning disclosure, community making or political engagement: as a thing, it is always engaged in gathering. Architecture always produces something more than what was stated in the brief for its construction, an increased value part of which is always deferred to a future. And this is a value that cannot be spent, exhausted or consumed nor in the present nor even in a distant future, because, as a meaningful construction, it is constantly reassessed. The profits that architecture produces are profits that can never be exhausted since they are not easily transformed into economical profits, but always depend on values that escape 
the economical reappropriation. They exceed the economical logic of accumulation and proclaim a different logic of distribution, that is aesthetical and disinterested, that is of course pleasurable but also desirable, and that is linked with gathering and reunion instead of extraction and separation. But it does not only pertain to the realm of aesthetics considered in the sense of the subjective reward or pleasure one can find in them, but to aesthetics in the sense of constant interrogation of our understanding of the world, of aesthetics as providing a different habits of perception that allow man to affect the world through a different media than science and technique.

\section{ARCHITECTURE AND TECHNIQUE. PHYSYS AND TECHNE}

The fact is that architecture always has been technical, always has performed its tasks through the implementation of different systems (circulatory and regulatory systems, structural systems, mechanical ones) based in a certain kind of performance, of active-passive response to the external demands, in a technical re-action against natural environment. This comes as back as Prometheus's myth, when the demi-god stole the fire to give it to men, and with the fire the knowledge of technique which allowed men to survive in nature. ${ }^{10}$

In architecture, from the structural timber frame of any primeval hut to the different openings and moving parts of this same hut, the door, the windows, the partition screens and so on, the mechanical answer formalized architecture from its very beginning, mythical or historical. Of course things changed from the beginning of nineteen century on, when the development of new technologies of construction and of design, from structural calculations to mechanical systems to an unprecedented level affected not only quantitatively but qualitatively architecture's own essence. The implementation of new technologies in architecture like elevators, mechanical ventilation, electricity and others, was rather timid at the beginning, at least from the point of view of the impact they had in the image of buildings, usually covered by a pseudohistorical approach to architectural essences. Nevertheless this mechanical fever won architecture at last to the point of virtual domination, a point arguably reached in the paradigmatic 1971 competition for the Centre Georges Pompidou in Paris, won by Renzo Piano and Richard Rogers.

The endless acceleration of technology and its deliberate visibility in architecture introduced a paradoxical twist to the question: technology, in its overwhelming presence, has become transparent as I already said. What does it means? That the different mechanical implementations that seem to make life easier, and that indeed do at the level of the simple biological demands, in its forefront visibility, in its ubiquitous presence, nevertheless, in a kind of delightful perversion, hide their own real nature, their perfunctory need for waste, by disconnecting its effect and the technical processes that allowed this effect to happen. If we thought technology came to fulfill our darkest desires, surely it does. If we thought it was for free, we are clearly wrong. We must cope with this kind of double bind: the more visible and exposed technology is, the more it tries to erase its own tracks, to disguise its own intrinsic need for excess, to dig inside the deep soil of invisibility its compulsive need for destruction. Since the moment we cannot see the connections between the effect of the mechanical instrument and the necessary consumption of energy nor only for performing its function but (and specially) for its construction and transport (another one of the big lies of globalization), the trick is accomplished. Transparency, in this sense, implies a voluntary dis-connection which accounts for irresponsibility: the veiling of the relationship between the turning on of a bulb switch and the huge process of waste and nature exploitation that lies behind left us unprotected and conveniently ignorant. Who ever think of in enormous reservoirs of water flooding entire areas in search of electricity to allow factories work at the cost not only of destroying natural landscapes but human life as well? Who of the massive scale electrical plants fueled by tons of coal or petroleum burned to ashes and polluting atmosphere, of radioactivity polluting waters and soil thousands of kilometers around, of the whole catalog of man-made disasters, so much celebrated for its engineered beauty and technological accomplishment when gently pressing the "on" button of our laptop in our comfortably warm home?

True, before and around the years in which the Pompidou Centre was designed, the Situationists's artistic research and political action, Constant's New Babylon or Archigram and their mobile and standstill superstructures and individual infra-structures gave as a kind of idea of what the possibilities of technology were, and also introduced, through pop imaginary and contra-cultural artillery, the soon forgotten seed of discomfort. Superstudio and Archizoom journeys into utopia spiced the mix and fueled the anarcho-structural criticism, both superseding the old jargon of dialectics and infrastructure-superstructure molds inherited from Marxism and favoring a too bland ironical critique to capitalism which sometimes looked more as surrender. But, technological or anti-technological, utopias always missed the point: not that we do not need a technology to survive or to improve our daily living in the nature, or even to colonize far distant planets, which is obvious we are in the need of. Nor even that technology will provide a delightful world of constant play, painted in the bright colors of altered estates of conscience,

\footnotetext{
${ }^{10}$ Plato gives a well account of this myth in his dialog Protagoras, 320d-322a.
}

Aesthetics Of Architectura: An Environmental Excess. José Vela Castillo.

DOI 10.14198/i2.2015.03.04 
which seems truer than ever. It is, on the contrary, than our very human life, our more intimate way of being in the world, and again we have to rely on Prometheus myth, seems to be technical. What constitute us as humans beyond being mere animals living in open nature is a fabrication, a construction, a production made according to a certain procedure in which calculation and invention are implied. And as any production, it implies, in fact demands, at the same time shortage and excess: both the supply of something that doesn't exist before but that we need to survive in nature, and in this point appears the obvious sin of the absentminded Epimeteus that forgot dispensing the human with natural qualities to survive into nature, and the excess any technique implies, the always present byproducts that fabrication creates. ${ }^{11}$ From language to architecture, our being is technical, at the cost of transforming but in fact destroying our environment, but also at the cost of investing us with a kind of second nature that is technical, one that apparently we couldn't rip off.

And as consequence of this technical construction, our being on the world generates waste, and not only because the misuse of the different raw materials we find in nature and extract from it, nor because a not so well developed technique charged with a bad efficiency ratio, but because any technical fabrication, by its very nature, produces waste. An excess that cannot be exhausted in the fabrication process from the initial raw material, contrary to how nature works. Technique is bound to the production of dubious byproducts that double, like a specter, the projected outcome of its fabrication. This double or specter, this especial rest that precisely rests and denies its obliteration, is an irreducible ash impossible to recycle and reintroduce into the cycle of production and consumption. Nature does not produce rests, since its production is always disinterested in human terms, has no utility or finality in mind in an ethical sense. It is a pure production, before the technical division of human construction and its need of governing nature. But it is not the case in human production, that has finality in mind, and that cannot absorb in the technical outcome the full possibilities of the raw, natural, material. Going back to Aristotle distinction between physis and techne, the physis (or nature) according Aristotle has the source of production-of movement and rest-in itself, whereas techne needs a source of motion outside itself. ${ }^{12}$ This means that techne depends and needs physis for being effective, and that also means that in human production, the technical one, the origin of the movement should be located in the producer, and not in the thing produced as when is nature the creator. And this disconnection between the source of movement and the production cannot be reduced to zero, thus fatally implying a distance between the two which is the source of excess, since excess in no other thing than an amount of something that is more than desirable.

Heidegger will take later on over Greek and particularly Aristotle's conception of techne in "Building, Dwelling, Thinking" to propose that techne, beyond technology and fabrication, will mean "to make something appear" and consequently for him "[T]he word techne denotes a mode of knowing", techne being then governed by aletheia or disclosing instead of by utilitarian production and then connected with the work of the artist. ${ }^{13}$ But by disregarding the Aristotelian difference between physis and techne concerning where the origin of movement of transformation is, he is only playing with words and attributing to techne a different meaning. Nevertheless, the problem persists: if for Heidegger techne is not production or fabrication or manufacturing of goods but a deeper understanding of the relation between human and being (the disclosure that aletheia implies), this means only transferring production to another level, but not getting rid of it. In any case, the discussion is important since aletheia as disclosure precisely implies visibility, the process of bringing forth what otherwise is hidden, and in that sense techne, should open up a world in which things are disclosed as they really are. Or so it seems.

But the question remains: could it be possible for architecture, as the technical production it is, set itself outside this fundamental dilemma between physis and techne, or between natural production as disinterested and perfectly efficient production and technical construction as end-intended and waste producing? Well, she probably can't. But what it can really do, instead of being the seat of dumb and invisible technologies, itself a dumb or blind machine that hides the source of the discomfort it produces, is transforming itself into a critical machine that points to the origin of the disconnection between man and nature and operates a process of visibilization or disclosure of its original essence. Or in other words, to re-establish an aesthetical origin for architecture based in disinterest but also in a distribution of the sensible world that enables a different politics of man and nature. Maybe it is not a reassuring answer, but at least has the advantages of being honest.

\footnotetext{
${ }^{11}$ Epimeteus was the brother of Prometeus. The latter allowed Epimeteus to distribute capacities and abilities to the different animals after their creation, but when it came the moment to furnish man, he had already all of them expended. Consequently, Prometheus needed to steal fire and technique to the gods to give men a possibility to survive in nature. See the account in Plato, Protagoras, 321c.

${ }_{12}^{12}$ Aristotle, Physics, book II, part 1.

${ }^{13}$ See Martin Heidegger "Building, Dwelling, Thinking" in Martin Heidegger, Poetry, Language, Thought (New York: Harper Colophon Books, 1971).
} 


\section{KANTIAN DISINTEREST}

Finally, at this point and to finish with, I want to come back to one important aspect of Kantian aesthetics. It is not that we have to return to Kant division between the two realms of necessity and freedom concerning nature and man, or that we must come back to transcendental aesthetics as the bases of our understanding of the relations between architecture and nature. Nevertheless, I think we should remember some Kantian ideas related with the question of disinterest as exposed in his Critique of Judgement, since maybe they could reframe the possibility of a different appreciation of architecture in its technical but mainly aesthetical relation with nature.

When Kant comes to describe how and from where our aesthetical appreciation comes in his Critique of Judgement the basic idea is that of disinterest. The second paragraph ( $\S 2$ ) of the Critique is aptly titled "The delight which determines the judgement of taste is independent of all interest." ${ }^{14}$ At first sight, it may seem that is precisely in the disinterest aesthetic judgment introduces in the real existence of things, in the privative particle of the dis, where it could lay one of the reasons of our negligence towards nature. And of course this will imply a painful aporia: if we could find aesthetical pleasure only through disinterest, it can be this very disinterest in nature the father of its destruction, because we will find some kind of guilty pleasure in showing our disinterest precisely for its existence, its conservation or its very utility, equating disinterest and despise.

Nevertheless, this is not the point with Kant, and what I want to stress here is the reverse view: it is precisely the disinterest in the existence of the object and the delight in it that allows aesthetic appreciation. A disinterest directed precisely to the gratuity of the very reward I find in the contemplation of the object, ${ }^{15}$ or better saying, the absence of this reward or delight. The possibility of founding beauty in an object is directly linked to the lack of interest both in the sense of the delight I find in its contemplation and of the interest in the existence of the object as the result of the possible use (its purposiveness). What interest me here is that aesthetical approach to nature is very different to technical one, since in this case one is not looking for any use or any profit to be found in nature, but on the contrary, one only will find reward if the approach totally lacks in interest. Aesthetical gaze in this Kantian sense will reverse the techno-scientific view that, according for example to Heidegger as has been mentioned, has turned nature into a repository of human needs, and only considers its existence in the ways it can serve us for one or other purpose.

In addition, Kant's aesthetical judgement is equally unrelated with desire or appetite, because for him, the universality of the judgement (the "this is beautiful") demand that it is not associated with personal or subjective circumstances (any private desire), but should be agreed by everybody. And this means too that I cannot have any personal interest extracted from the object, since in that case the judgment will not be of universal application, for everyone and in any time, as it should be. In that sense, this universality will imply precisely that nature cannot be appropriated by anybody.

What is more, later in the Critique, Kant will also introduce a distinction between free beauty and dependent beauty $(\S 16)$. The former "presupposes no concept of what the object should be" 16 , and for Kant can only be found in those objects that either we do not know what they are, as abstract or geometrical drawings without any intrinsic meaning, or in nature when we think of some flowers or animals that we are unaware of any possible end or utility they can have. ${ }^{17}$ On the contrary, dependent beauty, which is of a second rate, depends on the attachment of the object to a concept, and introduces the idea of an end in its concept.

Hence, if we say that a horse is a free beauty, we can only say that by taking apart all the possible uses or ends associated with the horse (its use as a working animal in the fields or as a race-horse in a hippodrome), and judging it devoid of any end or purposiveness. For Kant, in principle, the beauty of man or the beauty of a building is always a dependent beauty because it "presupposes a concept of the end that defines what the thing has to be, and consequently a concept of its perfection." ${ }^{18}$ And since the point in aesthetic judgement is that always "its determining ground is the feeling of the subject, and not any concept of an object," "spoiled" by the existence of the object that presupposes a certain end, beauty lacks in purity for the subject. But nevertheless is a kind of beauty, which, I think, is the beauty architecture must aspire to transcend, or at least not to exploit. Maybe architecture cannot free itself of being marked by this finality, but at least can try

\footnotetext{
${ }^{14}$ Immanuel Kant, Critique of Judgement (Oxford and New York: Oxford University Press, 2007), 36.

15 "The delight which we connect with the representation of the existence of an object is called interest" says Kant. Ibid.

${ }^{16}$ Ibid., 60.

17 True, Kant's vision is here slightly naive, and says a lot about the estate of biological knowledge at the time.

18 lbid.

${ }^{19}$ Ibid., 62.
} 
to, on the one hand to show through visibilization the results of its interest and on the other to offer some gratuity in compensation.

What is what I want to suggest after all as a final conclusion? That, difficult as it may be in Kantian terms, architecture should look for an origin that, instead of joining it with technique as in the works of Daedalus, and hence with the questions of utility, end, purposiveness, interest and so on, can free of them to regain, to the extent it is possible, a disinterested and gratuitous engagement with nature. Accordingly, instead of enveloping itself into a technogadgetry second skin, that as we have seen only tries to hide the monstrosity of its result and extract the guilty pleasure of the "bad" disinterest in nature, architecture should adopt a purely disinterested gaze. Is this possible? Well, the point is, instead, if there is any other possibility left for architecture to be a meaningful activity, and not a mere surrogate of capitalist global forces and the agent of the accelerated destruction of the planet in which we all live (nature and us). Tafuri's conclusion some fifty years ago was that architecture cannot really oppose in a critical way capitalism and that any meaningful architecture was, in the face of capitalist domination, in fact impossible. ${ }^{20}$ The diagnosis was shared by many others, including Massimo Cacciari, ${ }^{21}$ and in the years that have passed since it does not seem that relevant news to change this vision have happened. Nevertheless, the question remains, urgent than ever. Definitively, we should at least to try to transform the original lust architecture feels for nature into a different, disinterested, equal relation with it, both agents active in the sublunary world in desperately need for a key to survival.

\section{Bibliografía}

Aristotle, Physics.

Cacciari, Massimo. Architecture and Nihilism: On the Philosophy of Modern Architecture. New Haven: Yale University Press, 1993.

Derrida, Jacques. Given Time: I. Counterfeit Money. Chicago and London: The University of Chicago Press, 1992.

Frontisi-Ducroix, Françoise. Dédale. Mythologie de l'artisan en Grèce ancienne. Paris: Librairie François Maspero, 1975.

Heidegger, Martin. The Question Concerning Technology and Other Essays. New York and London: Garland, 1977.

Heidegger, Martin. Poetry, Language, Thought. New York: Harper Colophon Books, 1971.

Kant, Immanuel. Critique of Judgement. Oxford and New York: Oxford University Press, 2007.

Plato, Protagoras.

Latour, Bruno. "Facing Gaia. A new Inquiry into Natural Religion." Gifford lectures, Edimburgh University, 2013 (retrieved August 18, 2015):

http://www.ed.ac.uk/schools-departments/humanities-soc-sci/news-events/lectures/gifford-lectures/archive/series-2012-

2013/bruno-latour

Mauss, Marcel. The Gift: The Form and Reason for Exchange in Archaic Societies. London: Routledge, 2002.

Stengers, Isabelle. Cosmopolitics volume I and II. Minneapolis, MN: University of Minnesota Press: 2010 and 2011.

Tafuri, Manfredo. Architecture and Utopia. Design and Capitalist Development. Cambridge, Mass., and London: MIT Press, 1976.

Walker, Henry J. Theseus and Athens. New York and Oxford: Oxford University Press, 1995.

Vela Castillo, José. "I owe you an explanation". REIA \#3 (2014): 183-198.

Vela Castillo, José. "Aunque la mona se vista de seda mona se queda? Desnudez, animalidad, política y ciudad" en Revista Desierto \#3, "28 Celsius" (2014): 97-106.

\footnotetext{
${ }^{20}$ See especially the last chapter of Manfredo Tafuri, Architecture and Utopia. Design and Capitalist Development (Cambridge, Mass., and London: MIT Press, 1976). An initial short version was published in Italian in 1969, in Contropiano 1.

${ }^{21}$ See for example Massimo Cacciari, Architecture and Nihilism: On the Philosophy of Modern Architecture (New Haven: Yale University Press, 1993).
} 


\section{Biografía}

José Vela Castillo teaches architecture at IE University. He is architect and holds a Ph.D. in architecture (ETSAM, Spain). He is currently working in a Ph. D. in Philosophy (Faculty of Philosophy-UCM, Spain). His research is focused in philosophy, theory and the project of architecture, from a post-metaphysical and critical stance. His writing has been published in numerous journals (including: Conditions, Architecture and Culture, REIA, Arquitectura, Iluminaciones, Metalocus and Eikasia) and has been also presented and published at different international conferences (Knowing by Designing in Brussels, Theory by Design in Antwerpen, EURAU12 in Porto, Alvar Aalto Conference in Jyvaskyla, Educating Architects Towards Innovative Architecture in Istanbul, Icomos/CaH 20THC in Madrid, Un|Planbar: Agora und Void in Dresden...). In 2010 Vela Castillo published the book "(de)gustaciones gratuitas" on Derrida and Mies van der Rohe (translated in 2012 into Portuguese). He is also author of a book on the work of architect Richard Neutra. He is founding member of Intersección (Research Group on Philosophy and Architecture). He is member of the Editorial Board on the THREE CROSSES: ART, ARCHITECTURE, CRITICISM Series published by Cambridge Scholars Publishing. 